\title{
In Situ Atomic Force Microscopy Studies on Nucleation and Self-Assembly of Biogenic and Bio-Inspired Materials
}

\author{
Cheng Zeng ${ }^{1}$, Caitlin Vitale-Sullivan ${ }^{2}$ and Xiang Ma ${ }^{2,3, *}$ \\ 1 Department of Chemistry, Indiana University, Bloomington, IN 47403, USA; chzeng@umail.iu.edu \\ Department of Chemistry, Idaho State University, Pocatello, ID 83209, USA; vitacait@isu.edu \\ 3 Department of Chemistry, Grand View University, Des Moines, IA 50316, USA \\ * Correspondence: max@umail.iu.edu; Tel.: +1-515-263-2951
}

Received: 30 May 2017; Accepted: 16 August 2017; Published: 31 August 2017

\begin{abstract}
Through billions of years of evolution, nature has been able to create highly sophisticated and ordered structures in living systems, including cells, cellular components and viruses. The formation of these structures involves nucleation and self-assembly, which are fundamental physical processes associated with the formation of any ordered structure. It is important to understand how biogenic materials self-assemble into functional and highly ordered structures in order to determine the mechanisms of biological systems, as well as design and produce new classes of materials which are inspired by nature but equipped with better physiochemical properties for our purposes. An ideal tool for the study of nucleation and self-assembly is in situ atomic force microscopy (AFM), which has been widely used in this field and further developed for different applications in recent years. The main aim of this work is to review the latest contributions that have been reported on studies of nucleation and self-assembly of biogenic and bio-inspired materials using in situ AFM. We will address this topic by introducing the background of AFM, and discussing recent in situ AFM studies on nucleation and self-assembly of soft biogenic, soft bioinspired and hard materials.
\end{abstract}

Keywords: in situ atomic force microscopy; nucleation; self-assembly; biomaterials; biomimetic; bioinspired

\section{Introduction}

Nature has always been a fascinating source of inspiration for scientists and engineers. During billions of years of evolution, highly sophisticated and ordered structures in living systems with remarkable properties have been created [1,2]. These properties, such as physical mechanics, are often far better than those of the equivalent synthetic materials with similar chemical compositions. For example, spider silk [3] has a tensile strength comparable to steel, but with a higher flexibility and much less density [4-7], which makes it an ideal material for a wide variety of military, industrial, and consumer applications [8-11]. Moreover, biological systems are made with significantly weak components, such as soft proteins, brittle minerals and water. Finally, these highly ordered structures can form at mild temperature and pressure conditions spontaneously or with relatively low energy consumption, mainly through self-assembly [12,13]. Incorrect or undesired self-assembly processes can lead to malfunction or even diseases, such as Alzheimer's and Parkinson's [14]. Therefore, it is fundamentally important and interesting to determine nucleation and self-assembly pathways of biogenic materials in order to understand the mechanisms of living systems and provide a rationale for the design and production of new classes of materials, such as biochips, biosensors, and novel drugs [15]. 
Bio-inspired materials are a class of materials whose structure, function and/or property mimic those of biogenic materials or living matter [16-22]. The field of bio-inspired materials is highly interdisciplinary. It focuses on the understanding of biological synthesis, self-assembly and hierarchical organization of biogenic materials, and uses this understanding to design and produce new "bio-inspired" synthetic materials for diverse applications [23-30]. A few examples of bio-inspired materials include peptoid [31-33] inspired by peptide, light-harvesting photonic materials [34-44] that mimic photosynthesis, water collecting surfaces [45-52] inspired by the head-stander beetle, and organic-inorganic hybrid structures that mimic the hierarchical architecture of nacre or bone [53-60]. One critical limitation to the mimicking of biological structures in materials, however, lies in our insufficient understanding of how biogenic and bio-inspired materials self-assemble into sophisticated structures.

Atomic force microscopy (AFM) is an imaging tool which utilizes a nanometer-sized tip as a localized force sensor. Since its invention [61], it has been widely used to study biology specimens including nucleic acid [62-64], proteins [65], viruses [66,67], cells [68], etc. AFM generates topographic images by raster scanning over a sample surface. The most commonly applied imaging modes [69] are contact mode [70-72], tapping (semi-contact) mode [73-77], non-contact mode [78-81], and the newly developed peak-force tapping mode [82-86]. Contact mode generates high lateral forces while the tip is scanning over the surface, and therefore, is normally being used to image hard materials such as minerals, metals, glass and ceramics, whose Young's moduli $(E)$ are $>10 \mathrm{GPa}$. Tapping mode greatly reduces the lateral forces by oscillating the tip to realize only intermittent contacts with the sample $[74,76]$, and therefore, is used for soft materials such as cell membranes, biomolecules and some polymers $(E<10 \mathrm{GPa})$. However, the imaging force is difficult to accurately estimate. In peak force tapping mode, the tip-sample forces are directly controlled at ultralow levels while at the same time the lateral forces are minimized, providing a suitable imaging environment for soft biological samples [85]. By continuously imaging the same area of interest, AFM allows researchers to take snapshots of various processes, thus directly visualizing the dynamics. The observation of nucleation and self-assembly by AFM can reveal in situ single-particle dynamics with the potential of mechanical manipulation.

For studies of nucleation and self-assembly, in situ AFM (Scheme 1) is an ideal tool and has unique advantages over several other structural techniques (e.g., transmission electron microscope, scanning electron microscope, optical microscope, light scattering, and small angle X-ray scattering) $[69,87]$. AFM tip apex radius is normally on the order of a few to tens of nanometers. Thanks to the very small size of tip, AFM can achieve extremely high spatial resolution in both vertical (sub- $\AA$ ) and lateral (sub-nanometer) directions, which enables people to directly monitor the nucleation and growth of single assemblies, rather than bulk behavior. Besides, AFM requires simple sample preparation. It is a label free method. Unlike electron microscopy (EM) which requires freezing or drying and staining, samples can be imaged by AFM at physiological or near-reacting conditions, which creates a suitable environment for studies of living systems and synthetic materials. Furthermore, recent development of AFM enables simultaneous collections of topographical, mechanical and electronic/electrochemical properties of samples, generating multi-parametrical data to examine the system of interest. Lastly, high-speed AFM (HS-AFM) [65,88-92] has been applied to visualize processes at an imaging rate of $\sim 20$ frames per second, which provides new opportunities for researchers to further capture and comprehend nucleation and self-assembly processes with much higher temporal resolution [93-99]. One also has the option to greatly improve temporal resolution by sacrificing spatial information. As AFM uses a raster scanning approach to generate images, there are two perpendicular scan directions: fast scan direction and slow scan direction. In a normal operation, the AFM tip will scan in the fast scan direction to complete imaging all pixels in one line before it moves by one pixel along the slow scan direction to the next line. The slow scan can be disabled, which allows the tip to repeatedly scan over the same line. The recorded image will show the evolution of a line profile over time and is very good for studying dynamics of processes such as nucleation. 


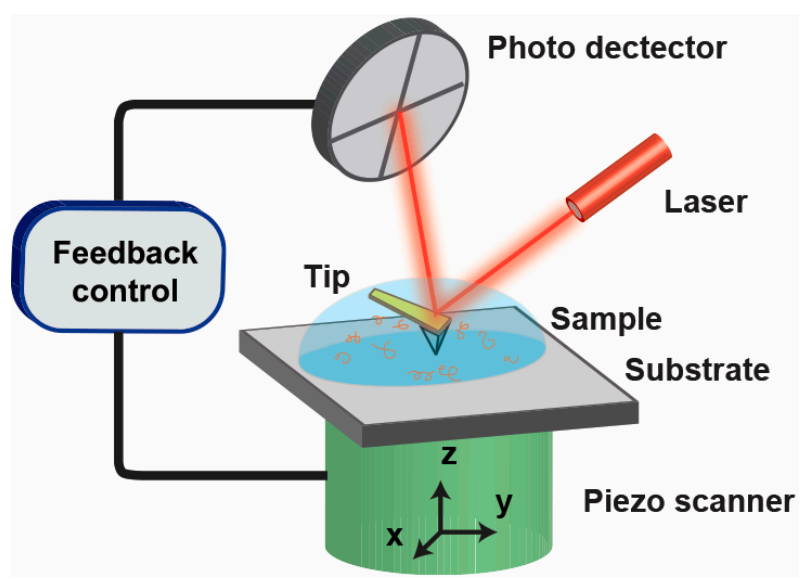

Scheme 1. Schematic illustration of in situ atomic force microscopy (AFM). The AFM tip is scanning on the surface to collect continuous images, while ions/molecules self-assemble into ordered structures in solution.

Besides imaging, AFM can also provide other physical information of the sample by measuring the force. For example, by (nano) indenting or stretching materials, their mechanical properties, such as adhesion and elasticity, can be precisely measured and mapped on the surface [100-104]. AFM-based nanoindentation and force spectroscopy has been applied to study many biological and bio-inspired systems, including bacterial adhesive material [105], viruses [106-118], proteins [119-125], nucleic acids [126-130], cells [131-133], and plant cell walls [134]. The mechanical properties of the materials can be connected to the processes of material nucleation and self-assembly [100-103].

In this review, a series of examples will be presented to illustrate the applications of in situ AFM and HS-AFM in the field of nucleation and self-assembly. These recent reports will be categorized into three groups based on their subjects: soft $(E<10 \mathrm{GPa})$ biogenic materials, soft bio-inspired materials, and hard $(E>10 \mathrm{GPa})$ materials. Since many previous review articles [135-144] have summarized AFM applications in nucleation of hard materials, this review will focus on soft materials.

\section{Soft Biogenic Materials}

\subsection{Peptide and Protein}

Alzheimer's disease is partially caused by the self-assembly and accumulation of fibrillar amyloid $\beta$ (A $\beta$ ) peptides in the brain [145]. Biophysical studies related to the self-assembly of $A \beta$ peptides have significantly improved our understanding of the mechanism of amyloid formation and its role in pathogenesis of Alzheimer's disease. The formation of amyloid fibril is believed to be a surface-mediated event [146]. As a surface sensitive technique, AFM is thus a very suitable candidate to study this process as the surface chemistry of substrate can be very well controlled. Lashuel and Dietler et al. investigated the mechanism of $A \beta$ fibril formation using in situ AFM [147]. They demonstrated that the structure and polymorphism of $A \beta$ fibrils are critically influenced by the oligomeric state of the starting materials, the ratio of monomeric-to-aggregated forms of $A \beta$ (oligomers and protofibrils), and the occurrence of secondary nucleation. They also demonstrated that monomeric $A \beta$ plays an important role in mediating structural transitions in the amyloid pathways. For the first time, they provided evidence for the existence of secondary-nucleation sites on the A $\beta$ fibrils. Their research findings have implications for understanding the molecular and structural basis of amyloid formation and development of therapeutic strategies for the treatment of Alzheimer's disease.

The requirement of using a nanometer-sized mechanical probe in AFM imaging brings in a unique way of tuning assembly: mechanical manipulation. Although AFM imaging force is normally kept small to prevent sample damage, people can also apply a higher force to initiate new events. Liu's group used an AFM probe to mechanically cut the amyloid fibrils, which are formed by mucin 1 
peptide fused with Q11 (MUC1-Q11), and observed growth of fibrils at the newly exposed termini using in situ AFM [148]. They showed that orientation and length of branched fibrils can be controlled by the nuclei orientation and reaction time. Therefore, local mechanical force can be used to affect the fibril formation and assembly of MUC1-Q11. Their approach offers a pure physical and label-free means to control the growth of MUC1 epitopes. In a similar case, $\mathrm{Hu}$ et al. demonstrated that a new peptide nanofilament can be introduced by mechanically generating an active end at designated positions on an existing filament [149]. The self-assembly of new filaments is specifically guided by the direction of new active ends.

Many soft bio-inspired materials are inherently connected to soft/hard interface or interphases (transitions of material properties, e.g., mechanical gradients) [150,151]. Disassembly of amelogenin, an enamel protein, onto hydroxyapatite (HAP) surfaces has been studied using high-resolution in situ AFM by Tao's group [152]. Their study showed that the amelogenin nanospheres disassemble onto the HAP surface, and then break down into oligomeric (25-mer) subunits of the larger nanosphere. The binding energy of the protein to a specific face of HAP (100) was extracted from quantification of the adsorbate amounts by size analysis. The kinetics of disassembly indicated a time-dependent increase in oligomer-oligomer binding interactions within the nanosphere. Their study elucidates the mechanism of supramolecular protein interactions and break down at surfaces.

Two dimensional (2D) assembly of S-layer proteins has been studied using in situ AFM on supported lipid bilayers by De Yoreo et al. Their results suggested that proteins undergo conformational transformations which direct the pathway of assembly. Monomers with an extended conformation first form a mobile adsorbed phase, and then condense into amorphous clusters, which undergo a phase transition through S-layer folding into crystalline clusters composed of compact tetramers [153]. They also showed that the system of S-layer proteins on mica possesses a kinetic trap associated with conformational differences between a long-lived transient state, which exhibits the characteristics of a kinetic trap in a folding funnel, and the final stable state [154].

HS-AFM has been utilized to visualize the fast dynamics of growth and assembly of lithosthatine, a protein produced by pancreas acinar cells, at a high imaging rate (one frame/s). Formation of fibrils via protofibril lateral association and stacking follows a zipper-like mechanism of association. They also demonstrated that two lithostathine protofibrils can associate to form helical fibrils (Figure 1) [99]. Their study provided new insights into lithostathine protofibril elongation and assembly.
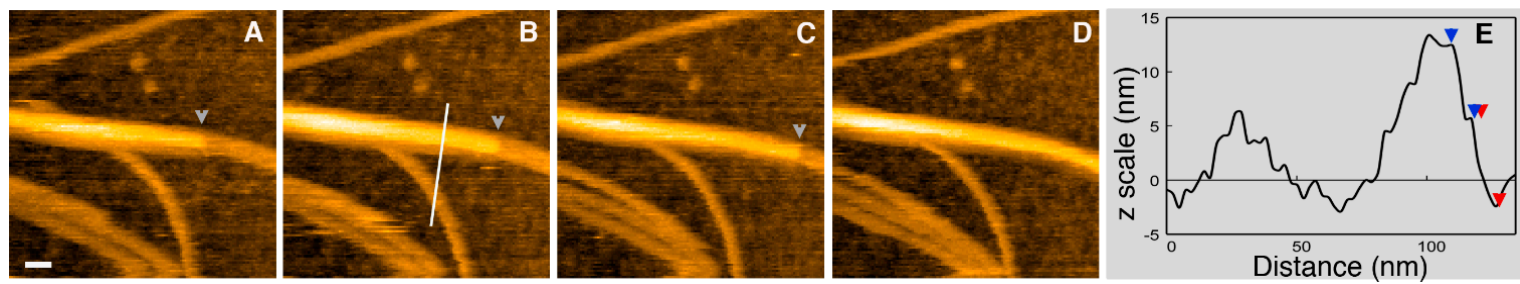

Figure 1. (A-D) Time lapse of the protofibril elongation stacked on top of a fibril. The grey arrowheads indicate the edge of the elongating protofibril on top of a fibril. (E) The profile (corresponding to the white line in (B)) indicates that only two fibers are stacked on top of each other. Images were collected successively separated by $1 \mathrm{~s}$. Scale bar: $30 \mathrm{~nm}$. Adapted from Ref. [99].

\subsection{Nucleic Acid}

Direct visualization of nucleic acids in aqueous solution has always been a challenging topic due to relatively weak interactions between nucleic acids and substrates. Appropriate modification of substrate surfaces and selection of force detection method can significantly enhance imaging quality and resolution [64]. For example, Yamada's group used an ultra-low-noise AFM, frequency modulation AFM (FM-AFM), to successfully observe local structures of native plasmid DNA in water. Even individual functional groups within DNA were clearly discerned [155]. In another case, Ye et al. 
utilized a carboxyl-terminated self-assembled monolayer modified gold surface where single-stranded DNA probes were covalently anchored for visualization of single DNA hybridization events using in situ AFM. By introducing $\mathrm{Ni}^{2+}$ ions (or some other divalent cations), the surface-DNA interaction can be switched between a strong state and a weak state, which accommodates for both high-resolution imaging and DNA hybridization [156,157].

\subsection{Lipid}

Lipid-protein/peptide interactions have been studied using in situ AFM to understand self-assembly of lipids and health-related mechanisms. Legleiter et al. have used in situ AFM to directly monitor the interaction between huntingtin (htt) exon 1 protein and brain lipid extract [158]. They observed that the exon 1 fragments accumulated on the lipid membranes comprised of total brain lipid extract, which caused disruption of the membrane. This disruption is dependent on length of polyQ in exon1. They also observed that adding an $\mathrm{N}$-terminal myc-tag to the htt exon1 fragments can prevent the interaction of htt with the bilayer. The interaction between melittin, a 26-residue amphipathic peptide, and lipid membranes has been studied using in situ AFM by Pan et al. [159]. Their results showed that melittin induced defects in lipid bilayers, which can be delayed by introducing cholesterol. They also proposed a kinetic defect growth model based on their AFM observations.

Kobayashi et al. used HS-AFM to investigate interactions between self-assembled sphingomyelin (SM)-cholesterol (Chol) lipid membranes and a SM-binding pore-forming toxin, lysenin. Lysenin recognized SM-rich domain and self-assembled into hexagonal close-packed (hcp) structure on the SM-rich domain, which did not perturb the phase boundary between SM and Chol. After the SM-rich domain is fully covered by lysenin, the hcp assembly started to occur in Chol liquid-disordered phase and eventually covered the entire membrane [160].

\section{Soft Bio-Inspired Materials}

\subsection{Peptoid}

Peptoid is a bio-inspired material, which has a structure similar to peptide but lacking hydrogen bonds between backbones. Because of this difference, peptoid has several advantages over peptide, such as high stability against temperature and protease degradation, flexibility and simplicity. Not until very recently, researchers started to appreciate the simplicity of peptoid systems and employ the system for studies on nucleation and self-assembly.

Ma et al. specifically designed a peptoid system to fundamentally understand the relationship between molecular sequence and structure [31]. They determined the dynamics and kinetics of nucleation and self-assembly of two peptoid molecules $\left(\mathrm{Pep}_{\mathrm{c}} \mathrm{vs.}\right.$. Pep $\mathrm{b}$ ) with similar sequence using in situ AFM. Ma's team, for the first time, provided direct evidence showing that nucleation pathways are indeed sequence dependent: a slight difference in sequence can switch nucleation pathway from classical to a two-step process (Figure 2, Scheme 2). They also proposed a mathematical model to explicitly explain and predict sequence-dependent selection of self-assembly pathways. Their research findings shed new light on non-classical nucleation pathways, which has implications in biology, chemistry, geology and biomedicine.

The sequence of peptoid can be tailored to self-assemble into 2D membranes [33]. These peptoid membranes self-assembled on mica through a process of heterogeneous nucleation and lateral growth. Details about kinetics and dynamics of self-assembly of 2D membranes have been studied. In situ AFM images showed that peptoid membranes exhibit self-repair properties and are highly stable. These membranes can provide a platform to incorporate and pattern a diverse range of functional objects either before assembly or by co-crystallization approaches. 

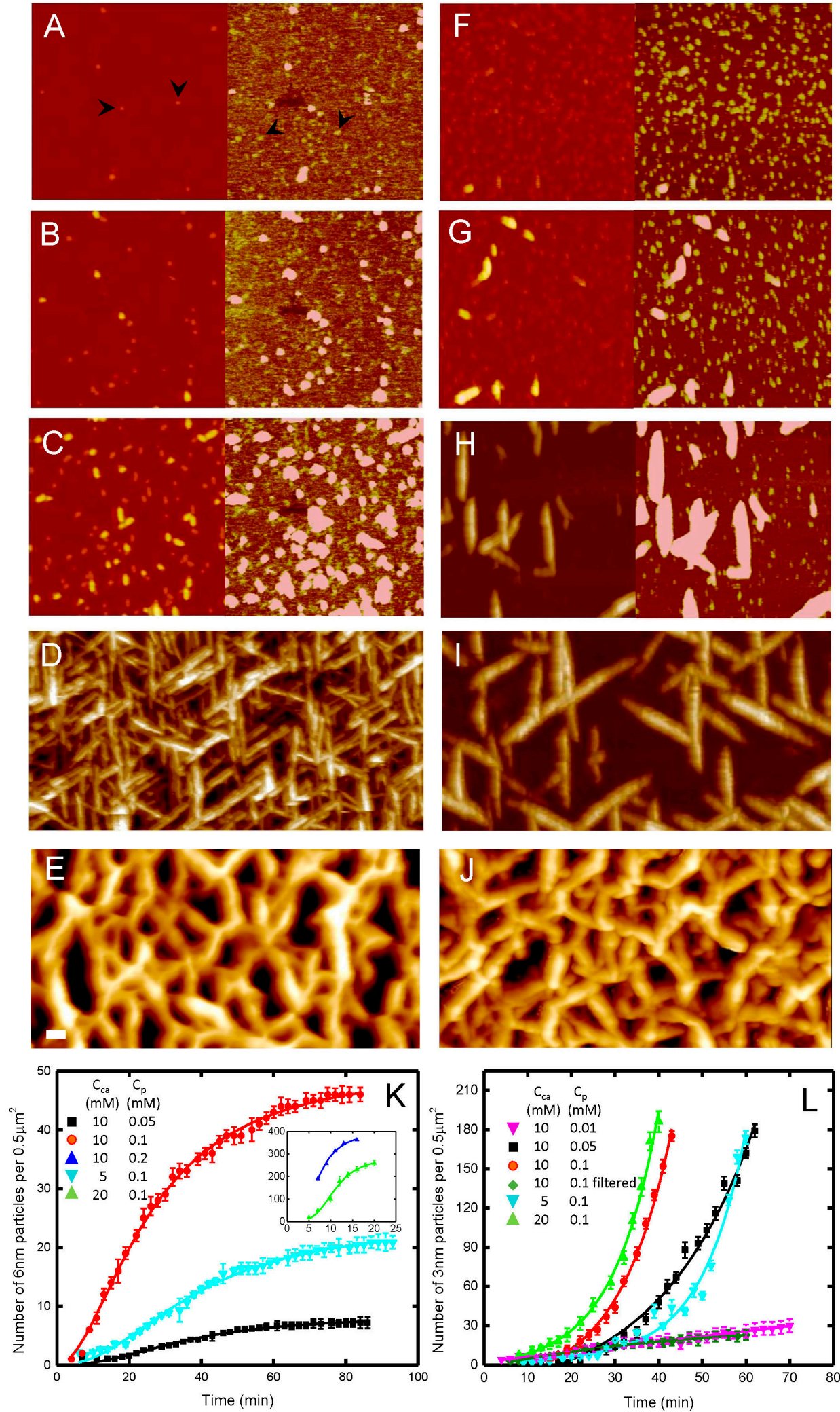

Figure 2. In situ view and kinetics of peptoid assembly. Nucleation and self-assembly of Pepc (A-E), and Pepb (F-J). (A-D,F-I): In situ AFM images showing assembly pathway of Pepc at $t=24.2$ (A); 32.3 (B); 50.1 (C) and 275.1 (D) min; and Pepb at $t=4.3$ (F); 17.2 (G); 69.1 (H); and 111.2 (I) min. (E,J): Ex situ AFM images showing self-assembled porous networks of Pepc (E) and Pepb (J). (K,L): Nuclei number density versus time for Pepc (K) and Pepb (L). Adapted from Ref. [31]. 
A

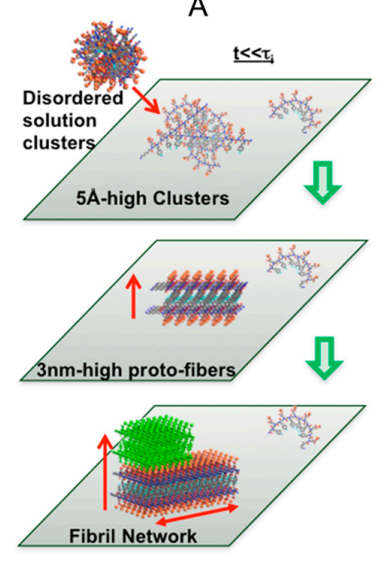

B

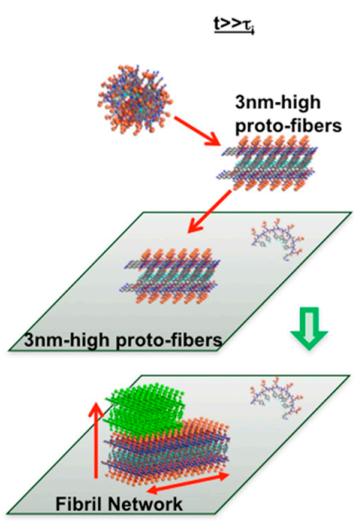

Scheme 2. Proposed model for the peptoid assembly process at early (A) and late (B) stages showing the effect of hydrophobic conjugate on the propensity for peptoid aggregation. Adapted from Ref. [31].

\subsection{Other Polymers}

The nucleation and growth of several bio-inspired polymers has been studied using in situ AFM. Interestingly, it was found that a carefully chosen surface can be used to facilitate self-assembly in such systems. For instance, Yip et al. revealed a distinct behavior of elastin-like peptides on difference surfaces: they form aggregates on mica, yet self-assemble into ordered fibrils on HOPG (highly ordered pyrolytic graphite) surface [14]. Such a difference shows that the hydrophobic peptide-substrate interactions are crucial for the formation of ordered structures. Their results provided direct evidence of frustrated fibril nuclei and oriented growth of independent fibril domains [161]. Similarly, Cohen Stuart et al. reported the self-assembly of a biosynthetic amino acid into fibrils on a charge silica surface, which would not happen in solution under the same buffer conditions due to the electrostatic repulsion between monomers carrying the same charges [162]. The presence of the substrate, which is negatively charged, stabilizes the positive charged monomers on surface and thus allows for heterogeneous nucleation of fibers. Zhou et al. observed "upright" fibrilar conformation for an amyloid-like peptide on mica surface, which is different from its "flat" conformation on the HOPG surface [163]. Zhou et al. also examined the effect of salt on self-assembly of amyloid-like peptides on mica [164].

As discussed above, self-assembly can be induced by a localized mechanical force applied by the AFM tip $[15,165,166]$. For instance, He et al. have shown an interesting in situ AFM based approach to pattern silk fibroin (SF) proteins on surface [15]. Specifically, they used an AFM tip to scan over a mica surface in a solution of SF monomers. After repeated scans on the same area, SF proteins are deposited onto the surface. Interestingly, such features can only be observed in areas where scanning was performed. On the contrary, the rest of the surface which was not extensively scanned by the AFM tip stayed clean. Such results suggest that the surface patterning was achieved upon contact of the tip and surface. This process was observed to occur in both contact mode and tapping mode. He et al. proposed that a sol-gel transition of the SF molecule is key to their deposition. In contact mode, this transition occurs at the tip-substrate interface as a result of shear force; whereas in tapping mode, the sol-gel transition of SF molecules is proposed to first occur on the tip due to tip oscillation, and the accumulated SF molecules are subsequently transferred to the surface upon tip-surface contact. The patterning process is governed by mechanical contact; thus, it can be manipulated by altering the scanning speed, which determines the frequency of tip-surface contact, and the force applied in each contact. In addition, the SF concentration is also very important. This approach is advantageous because, unlike conventional dip-pen lithography methods performed in air, patterning is achieved in liquid which possibly helps to retain the native structure of proteins.

Seog et al. reported a study of silk-elastin-like peptide (SELP), which is another example of mechanically induced self-assembly on surface with possibly a different mechanism [165]. Formation 
of SELP amyloid fibers was observed after repeated scanning the AFM tip over a single line, which is achieved by disabling the scan in the slow scan direction. In contrast to the previous example, fibers grow exclusively in the direction perpendicular to the scan direction of the tip. This directional bias suggests some specificity in nucleation. The proposed mechanism is that the AFM tip can stretch the SELP monomer to expose a domain which can interact with other peptides and lead to subsequent assembly.

Although the density of spontaneously formed fibers over the entire surface can be adjusted by concentration and buffer conditions, additional control on fiber growth over a local region can be achieved by nanomechanical manipulation. In a study of peptide EAK 16-II, which assemble into fibers on mica surface, Chen et al. reported that such fibers can be broken up by the imaging force applied in tapping mode AFM. Such fragments can then initiate new nucleation and growth into new fibers [166].

\section{Hard Materials}

\subsection{Calcium Phosphate}

It is important to determine the kinetics and dynamics during nucleation and growth of calcium phosphate (Ca-P) in order to understand several health-related issues, such as bone and tooth biomineralization [167], and pathological calcification in stones and in cardiovascular disease [168,169]. Very recently, Wang et al. examined nucleation of hydroxyapatite $\left(\mathrm{HAP}, \mathrm{Ca}_{10}\left(\mathrm{PO}_{4}\right)_{6}(\mathrm{OH})_{2}\right)$, a major component in bone and teeth, at different supersaturations using in situ AFM with long imaging times $(\sim 30 \mathrm{~h})$ to capture complete processes of HAP surface growth. They showed the morphology evolution during HAP surface growth, where a coexistence of a classical spiral growth by adding monomeric chemical species (molecules or ions) and nonclassical particle attachment by aggregating nanoparticles to form triangular solids which then transformed into hexagonal aggregates was observed [170] (Scheme 3). In another recent report, Wang's group studied the kinetics and mechanisms of Ca-P surface crystallization modulated by amelogenin [171]. They observed that, during in situ growth via a nonclassical particle attachment pathway, the assembly of amelogenin's C-termini induced an elongated aggregation of Ca-P nanoparticles, which directed Ca-P mineralization. They further determined the binding free energy of the C-terminal fragment absorbed to the (100) face of Ca-P using force spectroscopy to reveal mechanisms of shape evolution from spherical particles to elongated nanorods.

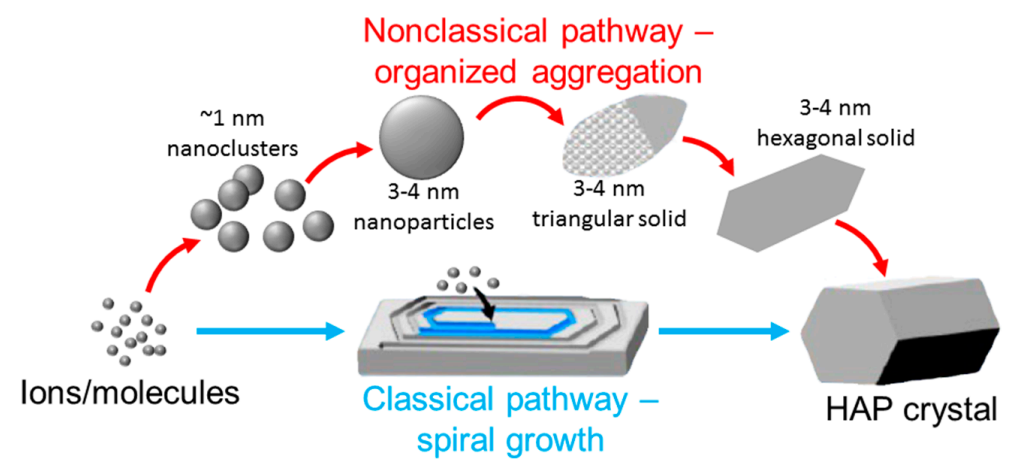

Scheme 3. Classical and nonclassical pathways for hydroxyapatite (HAP) crystallization. In the classical pathway, monomeric species (ions or molecules) are added at step edges during spiral growth, while in the nonclassical pathway, HAP crystals grow by the attachment of different size particles ( 1 $\mathrm{nm}$ or 3-4 $\mathrm{nm}$ in height) to form organized, but may be amorphous, assemblies/aggregates with triangular and hexagonal morphologies. 
Nucleation of HAP and amorphous calcium phosphate (ACP) on collagen has been studied using in situ AFM [172]. By measuring the rate of Ca-P nucleation as a function of supersaturation, they showed that ACP formation cannot be directly reconciled with classical nucleation theory. However, when taking into account the existence of pre-nucleation complexes and the particle size dependence of the interfacial free energy, the thermodynamic barrier for nucleation is dramatically lowered, which unites classical and non-classical nucleation theories-the observed non-classical route to ACP formation can be explained using classical theory.

\subsection{Calcite}

Biomineralization of Calcite $\left(\mathrm{CaCO}_{3}\right)$, the most abundant carbonate mineral on Earth and a common biomineral, has attracted researchers' interest for decades. The involvement of nonclassical nucleation pathways has been implied by previous studies, but only recently, direct evidence regarding the actual mechanism of calcite growth via an amorphous phase was reported. Rodriguez-Navarro et al. used in situ AFM to show that calcite can grow via a nonclassical particle-mediated colloidal crystal growth mechanism involving a layer-by-layer attachment of amorphous calcium carbonate (ACC) precursors, followed by restructuring and fusion with the calcite substrate in perfect crystallographic registry [173]. The transformation of ACC to calcite occurs through interface-coupled dissolution-reprecipitation and affects the nanogranular texture of the colloidal growth layer regulated by organic molecules. Another recent report by Colfen et al. indicates that polymer-induced liquid precursor phases play a role in nonclassical calcite crystallization and growth processes. They observed gel-like precursors, which spread out on the surface suggesting a liquid character, for the crystal growth on a calcite surface using in situ AFM [174].

The effects of inorganic and organic molecules/ions on calcite nucleation and growth have also been studied by in situ AFM. For example, Voitchovsky and Schmidt et al. investigated calcite (104)-water interface in the presence of $\mathrm{NaNO}_{3}$ [175]. In situ AFM images confirmed the alteration of crystallographic characteristics, and AFM force spectroscopy indicated the ability of dissolved $\mathrm{NaNO}_{3}$ to modify the structure of interfacial water. Wang and Putnis et al. showed that the presence of glucose-6-phosphate (G6P) changes the morphology of etch pits from the typical rhombohedral to a fan-shaped form, which can be explained by a site-selective mechanism of G6P-calcite surface interactions stabilizing the energetically unfavorable (0001) or (0112) faces through step-specific adsorption of G6P [176]. Wahl et al. observed specific binding of an acidic cement protein to step edge atoms on (1014) calcite surfaces. The protein then assembles to form one-dimensional nanofibrils, which affects the morphology of calcite [177].

\subsection{Calcium Oxalate Monohydrate}

Due to the clinical importance as the main inorganic component in human kidney stones, calcium oxalate monohydrate (COM) and regulation of its nucleation and growth has been of great interest for researchers. In situ AFM has been employed to investigate the effect of biomolecules, such as peptide, protein and nucleic acid, on COM growth. Huang and Qiu et al. performed a series of in situ AFM studies to understand the inhibitory effect of linear enantiomers of L- and D-Asp 6 on the growth of COM crystal [178]. They showed that D-Asp 6 has a larger inhibitory effect on the growth of the [100] step on the (010) face than L-Asp 6 . They further showed that these enantiomers create the impurity pinning along the steps, and the major impact of $\mathrm{Asp}_{6}$ is to block active kink sites. The inhibition of COM nucleation and aggregation by osteopontin (OPN) proteins has been investigated by Wang et al. Their data indicated that phosphorylated OPN peptides affect the step retreat rates via step-specific interactions, which in turn regulates the kinetics of COM nucleation and aggregation at the expense of brushite crystals by means of the interfacial mineral replacement reactions. Their research findings offer general insights concerning the control of kidney stone formation and the mechanisms through which aberrant crystallization kinetics is inhibited [179]. 


\section{Conclusions}

In this review, we summarized recent applications of in situ AFM to studies of nucleation and self-assembly of biogenic and bio-inspired materials, including peptide, protein, nucleic acid, lipid, peptoid, Ca-P, calcite and COM. Development of AFM techniques, such as in situ and HS-AFM, has enabled direct characterization of many biological and physicochemical processes which have never been revealed before.

Despite these key advancements, current AFM still has a number of limitations and technological issues, such as limited scan range (up to $\sim 1 \mu \mathrm{m}$ ), uncontrollable forces applied on the sample, and the lack of (bio)chemical specificity. The scan range has recently been increased to over $\sim 40 \times 40 \mu \mathrm{m}^{2}$, due to an implementation of an inversion-based feedforward control technique [180] and an enhanced iterative inverse control technique [181,182], although z-scanner still suffers from bandwidth limitation [65]. The peak-force tapping mode has been developed to directly control the force applied on the sample during scanning, which is beneficial for biological and soft material studies. The use of spatially resolved single-molecule force spectroscopy with AFM tips that are coated with specific chemical groups has enabled the detection and localization of single functional molecules on the surfaces of cells and other materials [183].

In the future, the applications of AFM will be further broadened into the fields of energy storage and conversion, catalysis, geology and biomedicine, especially due to the development of multimodal in situ imaging capabilities. For example, nanomechanical imaging can provide mechanical properties simultaneously; tip-enhanced Raman imaging can resolve chemical details spatially; current/conductive AFM imaging can give electronic and electrochemical properties of the samples; and AFM-based nanomanipulation can build three-dimensional nanostructures and nanodevices. Integrating AFM with other imaging, characterizing and manipulation techniques opens new avenues to understanding biological/chemical materials and processes comprehensively.

Acknowledgments: We thank the support from Idaho State University.

Author Contributions: C.V.-S. collected literature; C.Z. and X.M. wrote the paper.

Conflicts of Interest: The authors declare no conflict of interest.

\section{References}

1. Wainwright, S.A. Mechanical Design in Organisms; Princeton University Press: Princeton, NJ, USA, 1982.

2. Vincent, J.F. Structural Biomaterials; Princeton University Press: Princeton, NJ, USA, 2012.

3. Vollrath, F. Biology of spider silk. Int. J. Biol. Macromol. 1999, 24, 81-88. [CrossRef]

4. Heim, M.; Keerl, D.; Scheibel, T. Spider silk: From soluble protein to extraordinary fiber. Angew. Chem. Int. Ed. 2009, 48, 3584-3596. [CrossRef] [PubMed]

5. Gosline, J.M.; DeMont, M.E.; Denny, M.W. The structure and properties of spider silk. Endeavour 1986, 10, 37-43. [CrossRef]

6. Rammensee, S.; Slotta, U.; Scheibel, T.; Bausch, A. Assembly mechanism of recombinant spider silk proteins. Proc. Natl. Acad. Sci. USA 2008, 105, 6590-6595. [CrossRef] [PubMed]

7. Shao, Z.; Vollrath, F. Materials: Surprising strength of silkworm silk. Nature 2002, 418, 741. [CrossRef] [PubMed]

8. Hinman, M.B.; Jones, J.A.; Lewis, R.V. Synthetic spider silk: A modular fiber. Trends Biotechnol. 2000, 18, 374-379. [CrossRef]

9. Lee, S.-M.; Pippel, E.; Gösele, U.; Dresbach, C.; Qin, Y.; Chandran, C.V.; Bräuniger, T.; Hause, G.; Knez, M. Greatly increased toughness of infiltrated spider silk. Science 2009, 324, 488-492. [CrossRef] [PubMed]

10. O'Brien, J.P.; Fahnestock, S.R.; Termonia, Y.; Gardner, K.H. Nylons from nature: Synthetic analogs to spider silk. Adv. Mater. 1998, 10, 1185-1195. [CrossRef]

11. Lewis, R.V. Spider silk: Ancient ideas for new biomaterials. Chem. Rev. 2006, 106, 3762-3774. [CrossRef] [PubMed]

12. Whitesides, G.M.; Boncheva, M. Beyond molecules: Self-assembly of mesoscopic and macroscopic components. Proc. Natl. Acad. Sci. USA 2002, 99, 4769-4774. [CrossRef] [PubMed] 
13. Zhang, S. Fabrication of novel biomaterials through molecular self-assembly. Nat. Biotechnol. 2003, 21, 1171-1178. [CrossRef] [PubMed]

14. Yang, G.; Woodhouse, K.A.; Yip, C.M. Substrate-facilitated assembly of elastin-like peptides: Studies by variable-temperature in situ atomic force microscopy. J. Am. Chem. Soc. 2002, 124, 10648-10649. [CrossRef] [PubMed]

15. Zhong, J.; Ma, M.; Zhou, J.; Wei, D.; Yan, Z.; He, D. Tip-induced micropatterning of silk fibroin protein using in situ solution atomic force microscopy. ACS Appl. Mater. Interfaces 2013, 5, 737-746. [CrossRef] [PubMed]

16. Zhao, N.; Wang, Z.; Cai, C.; Shen, H.; Liang, F.; Wang, D.; Wang, C.; Zhu, T.; Guo, J.; Wang, Y. Bioinspired materials: From low to high dimensional structure. Adv. Mater. 2014, 26, 6994-7017. [CrossRef] [PubMed]

17. Chworos, A.; Smitthipong, W. Bio-inspired materials. In Bio-Based Composites for High-Performance Materials: From Strategy to Industrial Application; CRC Press: Boca Raton, FL, USA, 2014; Volume 43.

18. Barron, A.E.; Zuckerman, R.N. Bioinspired polymeric materials: In-between proteins and plastics. Curr. Opin. Chem. Biol. 1999, 3, 681-687. [CrossRef]

19. Sanchez, C.; Arribart, H.; Guille, M.M.G. Biomimetism and bioinspiration as tools for the design of innovative materials and systems. Nat. Mater. 2005, 4, 277-288. [CrossRef] [PubMed]

20. Wegst, U.G.; Bai, H.; Saiz, E.; Tomsia, A.P.; Ritchie, R.O. Bioinspired structural materials. Nat. Mater. 2015, 14, 23-36. [CrossRef] [PubMed]

21. Dujardin, E.; Mann, S. Bio-inspired materials chemistry. Adv. Mater. 2002, 14, 775. [CrossRef]

22. Aizenberg, J.; Fratzl, P. Biological and biomimetic materials. Adv. Mater. 2009, 21, 387-388. [CrossRef]

23. Sarikaya, M.; Tamerler, C.; Jen, A.K.-Y.; Schulten, K.; Baneyx, F. Molecular biomimetics: Nanotechnology through biology. Nat. Mater. 2003, 2, 577-585. [CrossRef] [PubMed]

24. Lindsey, J.S. Self-assembly in synthetic routes to molecular devices. Biological principles and chemical perspectives: A review. New J. Chem. 1991, 15, 153-179. [CrossRef]

25. Mayer, M.; Tebbe, M.; Kuttner, C.; Schnepf, M.J.; König, T.A.; Fery, A. Template-assisted colloidal self-assembly of macroscopic magnetic metasurfaces. Faraday Discuss. 2016, 191, 159-176. [CrossRef] [PubMed]

26. Pan, H.M.; Seuss, M.; Neubauer, M.P.; Trau, D.W.; Fery, A. Tuning the mechanical properties of hydrogel core-shell particles by inwards interweaving self-assembly. ACS Appl. Mater. Interfaces 2016, 8, 1493-1500. [CrossRef] [PubMed]

27. Kuttner, C.; Hanisch, A.; Schmalz, H.; Eder, M.; Schlaad, H.; Burgert, I.; Fery, A. Influence of the polymeric interphase design on the interfacial properties of (fiber-reinforced) composites. ACS Appl. Mater. Interfaces 2013, 5, 2469-2478. [CrossRef] [PubMed]

28. Kuttner, C.; Tebbe, M.; Schlaad, H.; Burgert, I.; Fery, A. Photochemical synthesis of polymeric fiber coatings and their embedding in matrix material: Morphology and nanomechanical properties at the fiber-matrix interface. ACS Appl. Mater. Interfaces 2012, 4, 3484-3492. [CrossRef] [PubMed]

29. Fratzl, P.; Burgert, I.; Gupta, H.S. On the role of interface polymers for the mechanics of natural polymeric composites. Phys. Chem. Chem. Phys. 2004, 6, 5575-5579. [CrossRef]

30. Kuttner, C. Macromolecular Interphases and Interfaces in Composite Materials; Verlag Dr. Hut: München, Germany, 2014.

31. Ma, X.; Zhang, S.; Jiao, F.; Newcomb, C.J.; Zhang, Y.; Prakash, A.; Liao, Z.; Baer, M.D.; Mundy, C.J.; Pfaendtner, J. Tuning crystallization pathways through sequence engineering of biomimetic polymers. Nat. Mater. 2017. [CrossRef] [PubMed]

32. Robertson, E.J.; Battigelli, A.; Proulx, C.; Mannige, R.V.; Haxton, T.K.; Yun, L.; Whitelam, S.; Zuckermann, R.N. Design, synthesis, assembly, and engineering of peptoid nanosheets. Acc. Chem. Res. 2016, 49, 379-389. [CrossRef] [PubMed]

33. Jin, H.; Jiao, F.; Daily, M.D.; Chen, Y.; Yan, F.; Ding, Y.-H.; Zhang, X.; Robertson, E.J.; Baer, M.D.; Chen, C.-L. Highly stable and self-repairing membrane-mimetic $2 \mathrm{~d}$ nanomaterials assembled from lipid-like peptoids. Nat. Commun. 2016, 7, 12252. [CrossRef] [PubMed]

34. Wagner, R.W.; Lindsey, J.S. A molecular photonic wire. J. Am. Chem. Soc. 1994, 116, 9759-9760. [CrossRef]

35. Nam, Y.S.; Shin, T.; Park, H.; Magyar, A.P.; Choi, K.; Fantner, G.; Nelson, K.A.; Belcher, A.M. Virus-templated assembly of porphyrins into light-harvesting nanoantennae. J. Am. Chem. Soc. 2010, 132, 1462-1463. [CrossRef] [PubMed] 
36. Calzaferri, G.; Bossart, O.; Brühwiler, D.; Huber, S.; Leiggener, C.; Van Veen, M.K.; Ruiz, A.Z. Light-harvesting host-guest antenna materials for quantum solar energy conversion devices. C. R. Chim. 2006, 9, 214-225. [CrossRef]

37. Choi, M.S.; Yamazaki, T.; Yamazaki, I.; Aida, T. Bioinspired molecular design of light-Harvesting multiporphyrin arrays. Angew. Chem. Int. Ed. 2004, 43, 150-158. [CrossRef] [PubMed]

38. Xu, J.; Guo, Z. Biomimetic photonic materials with tunable structural colors. J. Coll. Interface Sci. 2013, 406, 1-17. [CrossRef] [PubMed]

39. Andrews, D.L. Energy Harvesting Materials; World Scientific: Singapore, 2005.

40. Jacobs, M.; Lopez-Garcia, M.; Phrathep, O.-P.; Lawson, T.; Oulton, R.; Whitney, H.M. Photonic multilayer structure of begonia chloroplasts enhances photosynthetic efficiency. Nat. Plants 2016, 2, 16162. [CrossRef] [PubMed]

41. Calver, C.F.; Schanze, K.S.; Cosa, G. Biomimetic light-harvesting antenna based on the self-assembly of conjugated polyelectrolytes embedded within lipid membranes. ACS Nano 2016, 10, 10598-10605. [CrossRef] [PubMed]

42. Henry, S.L.; Withers, J.M.; Singh, I.; Cooper, J.M.; Clark, A.W.; Burley, G.A.; Cogdell, R.J. DNA-directed spatial assembly of photosynthetic light-harvesting proteins. Organ. Biomol. Chem. 2016, 14, 1359-1362. [CrossRef] [PubMed]

43. Hemmig, E.A.; Creatore, C.; Wünsch, B.; Hecker, L.; Mair, P.; Parker, M.A.; Emmott, S.; Tinnefeld, P.; Keyser, U.F.; Chin, A.W. Programming light-harvesting efficiency using DNA origami. Nano Lett. 2016, 16, 2369-2374. [CrossRef] [PubMed]

44. Kundu, S.; Patra, A. Nanoscale strategies for light harvesting. Chem. Rev. 2017, 117, 712-757. [CrossRef] [PubMed]

45. Parker, A.R.; Lawrence, C.R. Water capture by a desert beetle. Nature 2001, 414, 33-34. [CrossRef] [PubMed]

46. White, B.; Sarkar, A.; Kietzig, A.-M. Fog-harvesting inspired by the stenocara beetle-An analysis of drop collection and removal from biomimetic samples with wetting contrast. Appl. Surface Sci. 2013, 284, 826-836. [CrossRef]

47. Garrod, R.; Harris, L.; Schofield, W.; McGettrick, J.; Ward, L.; Teare, D.; Badyal, J. Mimicking a stenocara beetle's back for microcondensation using plasmachemical patterned superhydrophobic-superhydrophilic surfaces. Langmuir 2007, 23, 689-693. [CrossRef] [PubMed]

48. Pang, C.; Kim, S.M.; Rahmawan, Y.; Suh, K.-Y. Beetle-inspired bidirectional, asymmetric interlocking using geometry-tunable nanohairs. ACS Appl. Mater. Interfaces 2012, 4, 4225-4230. [CrossRef] [PubMed]

49. Zhu, H.; Guo, Z.; Liu, W. Biomimetic water-collecting materials inspired by nature. Chem. Commun. 2016, 52, 3863-3879. [CrossRef] [PubMed]

50. Zhu, H.; Guo, Z. Hybrid engineered materials with high water-collecting efficiency inspired by namib desert beetles. Chem. Commun. 2016, 52, 6809-6812. [CrossRef] [PubMed]

51. Zeng, X.; Qian, L.; Yuan, X.; Zhou, C.; Li, Z.; Cheng, J.; Xu, S.; Wang, S.; Pi, P.; Wen, X. Inspired by stenocara beetles: From water collection to high-efficiency water-in-oil emulsion separation. ACS Nano 2016, 11, 760-769. [CrossRef] [PubMed]

52. Zhang, S.; Huang, J.; Chen, Z.; Lai, Y. Bioinspired special wettability surfaces: From fundamental research to water harvesting applications. Small 2016. [CrossRef] [PubMed]

53. Espinosa, H.D.; Rim, J.E.; Barthelat, F.; Buehler, M.J. Merger of structure and material in nacre and bone-Perspectives on de novo biomimetic materials. Prog. Mater. Sci. 2009, 54, 1059-1100. [CrossRef]

54. Finnemore, A.; Cunha, P.; Shean, T.; Vignolini, S.; Guldin, S.; Oyen, M.; Steiner, U. Biomimetic layer-by-layer assembly of artificial nacre. Nat. Commun. 2012, 3, 966. [CrossRef] [PubMed]

55. Tang, Z.; Kotov, N.A.; Magonov, S.; Ozturk, B. Nanostructured artificial nacre. Nat. Mater. 2003, 2, $413-418$. [CrossRef] [PubMed]

56. Katti, K.S.; Mohanty, B.; Katti, D.R. Biomimetic Lessons Learnt from Nacre; INTECH Open Access: Rijeka, Croatia, 2010.

57. Li, C.; Born, A.K.; Schweizer, T.; Zenobi-Wong, M.; Cerruti, M.; Mezzenga, R. Amyloid-hydroxyapatite bone biomimetic composites. Adv. Mater. 2014, 26, 3207-3212. [CrossRef] [PubMed]

58. Thein-Han, W.; Misra, R. Biomimetic chitosan-nanohydroxyapatite composite scaffolds for bone tissue engineering. Acta Biomater. 2009, 5, 1182-1197. [CrossRef] [PubMed] 
59. Ng, J.; Spiller, K.; Bernhard, J.; Vunjak-Novakovic, G. Biomimetic approaches for bone tissue engineering. Tissue Eng. Part B Rev. 2017. [CrossRef] [PubMed]

60. Lopez-Heredia, M.A.; Łapa, A.; Mendes, A.C.; Balcaen, L.; Samal, S.K.; Chai, F.; Van der Voort, P.; Stevens, C.V.; Parakhonskiy, B.V.; Chronakis, I.S. Bioinspired, biomimetic, double-enzymatic mineralization of hydrogels for bone regeneration with calcium carbonate. Mater. Lett. 2017, 190, 13-16. [CrossRef]

61. Binnig, G.; Quate, C.F.; Gerber, C. Atomic force microscope. Phys. Rev. Lett. 1986, 56, 930-933. [CrossRef] [PubMed]

62. Bustamante, C.; Vesenka, J.; Tang, C.L.; Rees, W.; Guthold, M.; Keller, R. Circular DNA molecules imaged in air by scanning force microscopy. Biochemistry 1992, 31, 22-26. [CrossRef] [PubMed]

63. Hansma, H.G.; Sinsheimer, R.L.; Li, M.-Q.; Hansma, P.K. Atomic force microscopy of single-and double-stranded DNA. Nucleic Acids Res. 1992, 20, 3585-3590. [CrossRef] [PubMed]

64. Hansma, H.G.; Laney, D.E. DNA binding to mica correlates with cationic radius: Assay by atomic force microscopy. Biophys. J. 1996, 70, 1933-1939. [CrossRef]

65. Ando, T.; Uchihashi, T.; Kodera, N. High-speed afm and applications to biomolecular systems. Annu. Rev. Biophys. 2013, 42, 393-414. [CrossRef] [PubMed]

66. Kuznetsov, Y.G.; Malkin, A.J.; Lucas, R.W.; Plomp, M.; McPherson, A. Imaging of viruses by atomic force microscopy. J. Gen. Virol. 2001, 82, 2025-2034. [CrossRef] [PubMed]

67. De Pablo, P.J.; Carrión-Vázquez, M. Imaging biological samples with atomic force microscopy. Cold Spring Harb. Protoc. 2014, 2014, 167-177. [CrossRef] [PubMed]

68. Butt, H.J.; Wolff, E.K.; Gould, S.A.C.; Dixon Northern, B.; Peterson, C.M.; Hansma, P.K. Imaging cells with the atomic force microscope. J. Struct. Biol. 1990, 105, 54-61. [CrossRef]

69. Dufrêne, Y.F.; Ando, T.; Garcia, R.; Alsteens, D.; Martinez-Martin, D.; Engel, A.; Gerber, C.; Müller, D.J. Imaging modes of atomic force microscopy for application in molecular and cell biology. Nat. Nanotechnol. 2017, 12, 295-307. [CrossRef] [PubMed]

70. Rugar, D.; Hansma, P. Atomic force microscopy. Phys. Today 1990, 43, 23-30. [CrossRef]

71. Junno, T.; Anand, S.; Deppert, K.; Montelius, L.; Samuelson, L. Contact mode atomic force microscopy imaging of nanometer-Sized particles. Appl. Phys. Lett. 1995, 66, 3295-3297. [CrossRef]

72. Le Grimellec, C.; Lesniewska, E.; Giocondi, M.-C.; Finot, E.; Vié, V.; Goudonnet, J.-P. Imaging of the surface of living cells by low-force contact-mode atomic force microscopy. Biophys. J. 1998, 75, 695-703. [CrossRef]

73. Cleveland, J.; Anczykowski, B.; Schmid, A.; Elings, V. Energy dissipation in tapping-mode atomic force microscopy. Appl. Phys. Lett. 1998, 72, 2613-2615. [CrossRef]

74. Hansma, P.; Cleveland, J.; Radmacher, M.; Walters, D.; Hillner, P.; Bezanilla, M.; Fritz, M.; Vie, D.; Hansma, H.; Prater, C. Tapping mode atomic force microscopy in liquids. Appl. Phys. Lett. 1994, 64, 1738-1740. [CrossRef]

75. San Paulo, A.; Garcia, R. Unifying theory of tapping-mode atomic-force microscopy. Phys. Rev. B 2002, 66, 041406. [CrossRef]

76. Tamayo, J.; Garcia, R. Deformation, contact time, and phase contrast in tapping mode scanning force microscopy. Langmuir 1996, 12, 4430-4435. [CrossRef]

77. Kowalewski, T.; Holtzman, D.M. In situ atomic force microscopy study of alzheimer's $\beta$-amyloid peptide on different substrates: New insights into mechanism of $\beta$-sheet formation. Proc. Natl. Acad. Sci. USA 1999, 96, 3688-3693. [CrossRef] [PubMed]

78. Kitamura, S.-I.; Iwatsuki, M. Observation of $7 \times 7$ reconstructed structure on the silicon (111) surface using ultrahigh vacuum noncontact atomic force microscopy. Jpn. J. Appl. Phys. 1995, 34, L145. [CrossRef]

79. Morita, S.; Giessibl, F.J.; Meyer, E.; Wiesendanger, R. Noncontact Atomic Force Microscopy; Springer: Berlin, Germany, 2015; Volume 3.

80. Ramachandran, T.; Baur, C.; Bugacov, A.; Madhukar, A.; Koel, B.; Requicha, A.; Gazen, C. Direct and controlled manipulation of nanometer-sized particles using the non-contact atomic force microscope. Nanotechnology 1998, 9, 237. [CrossRef]

81. Sugimoto, Y.; Pou, P.; Abe, M.; Jelinek, P.; Pérez, R.; Morita, S.; Custance, O. Chemical identification of individual surface atoms by atomic force microscopy. Nature 2007, 446, 64-67. [CrossRef] [PubMed]

82. Trtik, P.; Kaufmann, J.; Volz, U. On the use of peak-force tapping atomic force microscopy for quantification of the local elastic modulus in hardened cement paste. Cem. Concr. Res. 2012, 42, 215-221. [CrossRef] 
83. Alsteens, D.; Dupres, V.; Yunus, S.; Latgé, J.-P.; Heinisch, J.J.; Dufrêne, Y.F. High-resolution imaging of chemical and biological sites on living cells using peak force tapping atomic force microscopy. Langmuir 2012, 28, 16738-16744. [CrossRef] [PubMed]

84. Zhao, B.; Song, Y.; Wang, S.; Dai, B.; Zhang, L.; Dong, Y.; Lü, J.; Hu, J. Mechanical mapping of nanobubbles by peakforce atomic force microscopy. Soft Matter 2013, 9, 8837-8843. [CrossRef]

85. Foster, B. New atomic force microscopy(afm) approaches life sciences gently, quantitatively, and correctively. Am. Lab. 2012, 44, 24-28.

86. Glatz, B.A.; Tebbe, M.; Kaoui, B.; Aichele, R.; Kuttner, C.; Schedl, A.E.; Schmidt, H.-W.; Zimmermann, W.; Fery, A. Hierarchical line-defect patterns in wrinkled surfaces. Soft Matter 2015, 11, 3332-3339. [CrossRef] [PubMed]

87. De Yoreo, J.J.; Chung, S.; Friddle, R.W. In situ atomic force microscopy as a tool for investigating interactions and assembly dynamics in biomolecular and biomineral systems. Adv. Funct. Mater. 2013, 23, 2525-2538. [CrossRef]

88. Schitter, G.; Astrom, K.J.; DeMartini, B.E.; Thurner, P.J.; Turner, K.L.; Hansma, P.K. Design and modeling of a high-speed afm-scanner. IEEE Trans. Control Syst. Technol. 2007, 15, 906-915. [CrossRef]

89. Fantner, G.E.; Schitter, G.; Kindt, J.H.; Ivanov, T.; Ivanova, K.; Patel, R.; Holten-Andersen, N.; Adams, J.; Thurner, P.J.; Rangelow, I.W. Components for high speed atomic force microscopy. Ultramicroscopy 2006, 106, 881-887. [CrossRef] [PubMed]

90. Sulchek, T.; Hsieh, R.; Adams, J.; Minne, S.; Quate, C.; Adderton, D. High-speed atomic force microscopy in liquid. Rev. Sci. Instrum. 2000, 71, 2097-2099. [CrossRef]

91. Hartman, B.; Andersson, S.; Nagel, W.; Leang, K. Non-raster high-speed afm imaging of biopolymers. Biophys. J. 2017, 112, 587a. [CrossRef]

92. Takahashi, H.; Miyagi, A.; Redondo-Morata, L.; Scheuring, S. Development of temperature-controlled high-speed afm. Biophys. J. 2017, 112, 587a. [CrossRef]

93. Katan, A.J.; Dekker, C. High-speed afm reveals the dynamics of single biomolecules at the nanometer scale. Cell 2011, 147, 979-982. [CrossRef] [PubMed]

94. Ando, T.; Kodera, N.; Takai, E.; Maruyama, D.; Saito, K.; Toda, A. A high-speed atomic force microscope for studying biological macromolecules. Proc. Natl. Acad. Sci. USA 2001, 98, 12468-12472. [CrossRef] [PubMed]

95. Uchihashi, T.; Iino, R.; Ando, T.; Noji, H. High-speed atomic force microscopy reveals rotary catalysis of rotorless f1-atpase. Science 2011, 333, 755-758. [CrossRef] [PubMed]

96. Ruan, Y.; Miyagi, A.; Wang, X.; Chami, M.; Boudker, O.; Scheuring, S. Direct visualization of glutamate transporter elevator mechanism by high-speed afm. Proc. Natl. Acad. Sci. USA 2017, 114, 1584-1588. [CrossRef] [PubMed]

97. Kotani, N.; Kumaresan, R.; Kawamoto-Ozaki, Y.; Morii, T.; Okada, T. High-speed afm reveals advanced details on dynamic behavior of antibody. Biophys. J. 2017, 112, 587a. [CrossRef]

98. Watanabe-Nakayama, T.; Ono, K.; Itami, M.; Takahashi, R.; Teplow, D.B.; Yamada, M. High-speed atomic force microscopy reveals structural dynamics of amyloid $\beta 1-42$ aggregates. Proc. Natl. Acad. Sci. USA 2016, 113, 5835-5840. [CrossRef] [PubMed]

99. Milhiet, P.-E.; Yamamoto, D.; Berthoumieu, O.; Dosset, P.; Le Grimellec, C.; Verdier, J.-M.; Marchal, S.; Ando, T. Deciphering the structure, growth and assembly of amyloid-like fibrils using high-speed atomic force microscopy. PLoS ONE 2010, 5, e13240. [CrossRef] [PubMed]

100. Zlotnikov, I.; Zolotoyabko, E.; Fratzl, P. Nano-scale modulus mapping of biological composite materials: Theory and practice. Prog. Mater. Sci. 2017, 87, 292-320. [CrossRef]

101. Gal, A.; Wirth, R.; Kopka, J.; Fratzl, P.; Faivre, D.; Scheffel, A. Macromolecular recognition directs calcium ions to coccolith mineralization sites. Science 2016, 353, 590-593. [CrossRef] [PubMed]

102. Casdorff, K.; Keplinger, T.; Bellanger, H.; Michen, B.; Schön, S.; Burgert, I. High-resolution adhesion mapping of the odd-even effect on a layer-by-layer coated biomaterial by atomic-force-microscopy. ACS Appl. Mater. Interfaces 2017, 9, 13793-13800. [CrossRef] [PubMed]

103. Li, Q.; Zhang, T.; Pan, Y.; Ciacchi, L.C.; Xu, B.; Wei, G. Afm-based force spectroscopy for bioimaging and biosensing. RSC Adv. 2016, 6, 12893-12912. [CrossRef]

104. Alsteens, D.; Newton, R.; Schubert, R.; Martinez-Martin, D.; Delguste, M.; Roska, B.; Müller, D.J. Nanomechanical mapping of first binding steps of a virus to animal cells. Nat. Nanotechnol. 2017, 12, 177-183. [CrossRef] [PubMed] 
105. Berne, C.C.; Ma, X.; Licata, N.A.; Neves, B.R.; Setayeshgar, S.; Brun, Y.V.; Dragnea, B. Physiochemical properties of caulobacter crescentus holdfast: A localized bacterial adhesive. J. Phys. Chem. B 2013, 117, 10492-10503. [CrossRef] [PubMed]

106. Vaughan, R.; Tragesser, B.; Ni, P.; Ma, X.; Dragnea, B.; Kao, C.C. The tripartite virions of the brome mosaic virus have distinct physical properties that affect the timing of the infection process. J. Virol. 2014, 88, 6483-6491. [CrossRef] [PubMed]

107. Ni, P.; Wang, Z.; Ma, X.; Das, N.C.; Sokol, P.; Chiu, W.; Dragnea, B.; Hagan, M.; Kao, C.C. An examination of the electrostatic interactions between the $n$-terminal tail of the brome mosaic virus coat protein and encapsidated rnas. J. Mol. Biol. 2012, 419, 284-300. [CrossRef] [PubMed]

108. Kol, N.; Shi, Y.; Tsvitov, M.; Barlam, D.; Shneck, R.Z.; Kay, M.S.; Rousso, I. A stiffness switch in human immunodeficiency virus. Biophys. J. 2007, 92, 1777-1783. [CrossRef] [PubMed]

109. Castellanos, M.; Pérez, R.; Carrasco, C.; Hernando-Pérez, M.; Gómez-Herrero, J.; de Pablo, P.J.; Mateu, M.G. Mechanical elasticity as a physical signature of conformational dynamics in a virus particle. Proc. Natl. Acad. Sci. USA 2012, 109, 12028-12033. [CrossRef] [PubMed]

110. Marchetti, M.; Wuite, G.; Roos, W. Atomic force microscopy observation and characterization of single virions and virus-like particles by nano-indentation. Curr. Opin. Virol. 2016, 18, 82-88. [CrossRef] [PubMed]

111. Denning, D.; Wuite, G.J.; Roos, W.H. A combined imaging and force spectroscopy approach reveals the material properties of viral nanoparticles. Biophys. J. 2016, 110, 500a. [CrossRef]

112. Ramalho, R.; Rankovic, S.; Zhou, J.; Aiken, C.; Rousso, I. Analysis of the mechanical properties of wild type and hyperstable mutants of the hiv-1 capsid. Retrovirology 2016, 13, 17. [CrossRef] [PubMed]

113. Korneev, D.; Popova, A.; Generalov, V.; Zaitsev, B. Atomic force microscopy-based single virus particle spectroscopy. Biophysics 2016, 61, 413-419. [CrossRef]

114. Snijder, J.; Kononova, O.; Barbu, I.M.; Uetrecht, C.; Rurup, W.F.; Burnley, R.J.; Koay, M.S.; Cornelissen, J.J.; Roos, W.H.; Barsegov, V. Assembly and mechanical properties of the cargo-free and cargo-loaded bacterial nanocompartment encapsulin. Biomacromolecules 2016, 17, 2522-2529. [CrossRef] [PubMed]

115. Quintana-Cataño, C.A.; Vives-Flórez, M.J.; Forero-Shelton, M. Force spectroscopy of $t 4$ bacteriophage adhesion during infection. Biophys. J. 2017, 112, 588a. [CrossRef]

116. Hernando-Perez, M.; Zeng, C.; Delalande, L.; Tsvetkova, I.; Bousquet, A.; Tayachi-Pigeonnat, M.; Temam, R.; Dragnea, B. Nanoindentation of isometric viruses on deterministically corrugated substrates. J. Phys. Chem. B 2016, 120, 340-347. [CrossRef] [PubMed]

117. Zeng, C.; Moller-Tank, S.; Asokan, A.; Dragnea, B. Probing the link among genomic cargo, contact mechanics, and nanoindentation in recombinant adeno-associated virus 2. J. Phys. Chem. B 2017, 121, 1843-1853. [CrossRef] [PubMed]

118. Delalande, L.; Tsvetkova, I.B.; Zeng, C.; Bond, K.; Jarrold, M.; Dragnea, B. Catching a virus in a molecular net. Nanoscale 2016, 8, 16221-16228. [CrossRef] [PubMed]

119. Eeftens, J.; Katan, A.; Kschonsak, M.; Hassler, M.; Dief, E.; de Wilde, L.; Haering, C.; Dekker, C. Single-molecule experiments to resolve structural and mechanical properties of condensin. Biophys. J. 2016, 110, 528a. [CrossRef]

120. Heinze, K.; Sasaki, E.; King, N.; Baker, D.; Hilvert, D.; Wuite, G.; Roos, W. Protein nanocontainers from nonviral origin: Testing the mechanics of artificial and natural protein cages by afm. J. Phys. Chem. B 2016, 120, 5945-5952. [CrossRef] [PubMed]

121. Moreno-Madrid, F.; Martín-González, N.; Llauró, A.; Ortega-Esteban, A.; Hernando-Pérez, M.; Douglas, T.; Schaap, I.A.; de Pablo, P.J. Atomic force microscopy of virus shells. Biochem. Soc. Trans. 2017, 45, 499-511. [CrossRef] [PubMed]

122. Zhang, X.F.; Xu, Y.; McKinnon, T.A.; Zhang, W. Biophysical mechanisms of von willebrand factor-collagen interactions. Biophys. J. 2017, 112, 455a. [CrossRef]

123. Van Patten, W.J.; Walder, R.; Adhikari, A.; Ravichandran, R.; Tinberg, C.E.; Baker, D.; Perkins, T.T. A computationally designed protein-ligand interaction is mechanically robust. Biophys. J. 2017, 112, 455a. [CrossRef]

124. Yadav, A.; Paul, S.; Venkatramani, R.; Rama, S.; Ainavarapu, K. Examining the mechanical properties of copper binding azurin using single molecule force spectroscopy and steered molecular dynamics. Biophys. J. 2016, 110, 496a. [CrossRef] 
125. Hughes, M.L.; Dougan, L. The physics of pulling polyproteins: A review of single molecule force spectroscopy using the afm to study protein unfolding. Rep. Prog. Phys. 2016, 79, 076601. [CrossRef] [PubMed]

126. Walder, R.; Van Patten, W.J.; Miller, T.W.; Perkins, T.T. Mechanical characterization of the hiv-1 rna hairpin using an atomic force microscope. Biophys. J. 2017, 112, 166a. [CrossRef]

127. Shlyakhtenko, L.S.; Dutta, S.; Li, M.; Harris, R.S.; Lyubchenko, Y.L. Single-molecule force spectroscopy studies of apobec3a-single-stranded DNA complexes. Biochemistry 2016, 55, 3102-3106. [CrossRef] [PubMed]

128. Fitzgibbon, C.J.; Josephs, E.A.; Marszalek, P.E. Resolving individual damage sites in DNA with afm using reengineered repair proteins. Biophys. J. 2016, 110, 496a. [CrossRef]

129. Dutta, S.; Armitage, B.A.; Lyubchenko, Y.L. Probing of minipeg $\gamma$-pna-dna hybrid duplex stability with afm force spectroscopy. Biochemistry 2016, 55, 1523-1528. [CrossRef] [PubMed]

130. Camunas-Soler, J.; Ribezzi-Crivellari, M.; Ritort, F. Elastic properties of nucleic acids by single-molecule force spectroscopy. Annu. Rev. Biophys. 2016, 45, 65-84. [CrossRef] [PubMed]

131. Fisher, G.J.; Shao, Y.; He, T.; Qin, Z.; Perry, D.; Voorhees, J.J.; Quan, T. Reduction of fibroblast size/mechanical force down-regulates tgf- $\beta$ type ii receptor: Implications for human skin aging. Aging Cell 2016, 15, 67-76. [CrossRef] [PubMed]

132. Rianna, C.; Radmacher, M. Cell Mechanics As a Marker for Diseases: Biomedical Applications of Afm. In AIP Conference Proceedings; AIP Publishing: Melville, NY, USA, 2016; p. 020057.

133. Ting, A.Y.P. Spatially resolved mapping of endogenous proteins and rna in living cells. Biophys. J. 2017, 112, 7a. [CrossRef]

134. Burgert, I.; Keplinger, T. Plant micro-and nanomechanics: Experimental techniques for plant cell-wall analysis. J. Exp. Bot. 2013, 64, 4635-4649. [CrossRef] [PubMed]

135. Wang, L.; Nancollas, G.H. Pathways to biomineralization and biodemineralization of calcium phosphates: The thermodynamic and kinetic controls. Dalton Trans. 2009, 2665-2672. [CrossRef] [PubMed]

136. Putnis, A.; Pina, C.M.; Astilleros, J.M.; Fernández-Díaz, L.; Prieto, M. Nucleation of solid solutions crystallizing from aqueous solutions. Phil. Trans. R. Soc. Lond. A 2003, 361, 615-632. [CrossRef] [PubMed]

137. Gao, Y.; Wang, J.; Zhong, J.; Wang, Y.; Yin, Q.; Hou, B.; Hao, H. Application of atomic force microscopy in understanding crystallization process. Sci. Adv. Mater. 2017, 9, 89-101. [CrossRef]

138. Jun, Y.-S.; Kim, D.; Neil, C.W. Heterogeneous nucleation and growth of nanoparticles at environmental interfaces. Acc. Chem. Res. 2016, 49, 1681-1690. [CrossRef] [PubMed]

139. Wang, L.; Lu, J.; Xu, F.; Zhang, F. Dynamics of crystallization and dissolution of calcium orthophosphates at the near-molecular level. Chin. Sci. Bull. 2011, 56, 713-721. [CrossRef]

140. Motta, N.; Szkutnik, P.D.; Tomellini, M.; Sgarlata, A.; Fanfoni, M.; Patella, F.; Balzarotti, A. Role of patterning in islands nucleation on semiconductor surfaces. C. R. Phys. 2006, 7, 1046-1072. [CrossRef]

141. Wesson, J.A.; Ward, M.D. Role of crystal surface adhesion in kidney stone disease. Curr. Opin. Nephrol. Hypertens. 2006, 15, 386-393. [CrossRef] [PubMed]

142. Alamani, B.G.; Rimer, J.D. Molecular modifiers of kidney stones. Curr. Opin. Nephrol. Hypertens. 2017, 26, 256-265. [CrossRef] [PubMed]

143. Rimer, J.D.; Kolbach-Mandel, A.M.; Ward, M.D.; Wesson, J.A. The role of macromolecules in the formation of kidney stones. Urolithiasis 2017, 45, 57-74. [CrossRef] [PubMed]

144. Han, L.; Ohsuna, T.; Liu, Z.; Alfredsson, V.; Kjellman, T.; Asahina, S.; Suga, M.; Ma, Y.; Oleynikov, P.; Miyasaka, K. Structures of silica-based nanoporous materials revealed by microscopy. Z. Anorg. Allg. Chem. 2014, 640, 521-536. [CrossRef]

145. Glenner, G.G.; Wong, C.W. Alzheimer's disease: Initial report of the purification and characterization of a novel cerebrovascular amyloid protein. Biochem. Biophys. Res. Commun. 1984, 120, 885-890. [CrossRef]

146. Zhai, J.; Lee, T.-H.; Small, D.H.; Aguilar, M.-I. Characterization of early stage intermediates in the nucleation phase of a $\beta$ aggregation. Biochemistry 2012, 51, 1070-1078. [CrossRef] [PubMed]

147. Jeong, J.S.; Ansaloni, A.; Mezzenga, R.; Lashuel, H.A.; Dietler, G. Novel mechanistic insight into the molecular basis of amyloid polymorphism and secondary nucleation during amyloid formation. J. Mol. Biol. 2013, 425, 1765-1781. [CrossRef] [PubMed]

148. Karsai, A.; Slack, T.J.; Malekan, H.; Khoury, F.; Lin, W.F.; Tran, V.; Cox, D.; Toney, M.; Chen, X.; Liu, G.Y. Local mechanical perturbation provides an effective means to regulate the growth and assembly of functional peptide fibrils. Small 2016, 12, 6407-6415. [CrossRef] [PubMed] 
149. Zhang, F.-C.; Zhang, F.; Su, H.-N.; Li, H.; Zhang, Y.; Hu, J. Mechanical manipulation assisted self-assembly to achieve defect repair and guided epitaxial growth of individual peptide nanofilaments. ACS Nano 2010, 4, 5791-5796. [CrossRef] [PubMed]

150. Dunlop, J.W.; Fratzl, P. Biological composites. Annu. Rev. Mater. Res. 2010, 40, 1-24. [CrossRef]

151. Dunlop, J.W.; Weinkamer, R.; Fratzl, P. Artful interfaces within biological materials. Mater. Today 2011, 14, 70-78. [CrossRef]

152. Tao, J.; Buchko, G.W.; Shaw, W.J.; De Yoreo, J.J.; Tarasevich, B.J. Sequence-defined energetic shifts control the disassembly kinetics and microstructure of amelogenin adsorbed onto hydroxyapatite (100). Langmuir 2015, 31, 10451. [CrossRef] [PubMed]

153. Chung, S.; Shin, S.-H.; Bertozzi, C.R.; De Yoreo, J.J. Self-catalyzed growth of s layers via an amorphous-to-crystalline transition limited by folding kinetics. Proc. Natl. Acad. Sci. USA 2010, 107, 16536-16541. [CrossRef] [PubMed]

154. Shin, S.-H.; Chung, S.; Sanii, B.; Comolli, L.R.; Bertozzi, C.R.; De Yoreo, J.J. Direct observation of kinetic traps associated with structural transformations leading to multiple pathways of s-layer assembly. Proc. Natl. Acad. Sci. USA 2012, 109, 12968-12973. [CrossRef] [PubMed]

155. Ido, S.; Kimura, K.; Oyabu, N.; Kobayashi, K.; Tsukada, M.; Matsushige, K.; Yamada, H. Beyond the helix pitch: Direct visualization of native DNA in aqueous solution. ACS Nano 2013, 7, 1817-1822. [CrossRef] [PubMed]

156. Abel, G.R., Jr.; Josephs, E.A.; Luong, N.; Ye, T. A switchable surface enables visualization of single DNA hybridization events with atomic force microscopy. J. Am. Chem. Soc. 2013, 135, 6399-6402. [CrossRef] [PubMed]

157. Thomson, N.H.; Kasas, S.; Smith, B.; Hansma, H.G.; Hansma, P.K. Reversible binding of DNA to mica for afm imaging. Langmuir 1996, 12, 5905-5908. [CrossRef]

158. Burke, K.A.; Hensal, K.M.; Umbaugh, C.S.; Chaibva, M.; Legleiter, J. Huntingtin disrupts lipid bilayers in a polyq-length dependent manner. Biochim. Biophys. Acta (BBA)-Biomembr. 2013, 1828, 1953-1961. [CrossRef] [PubMed]

159. Pan, J.; Khadka, N.K. Kinetic defects induced by melittin in model lipid membranes: A solution atomic force microscopy study. J. Phys. Chem. B 2016, 120, 4625-4634. [CrossRef] [PubMed]

160. Yilmaz, N.; Kobayashi, T. Visualization of lipid membrane reorganization induced by a pore-forming toxin using high-speed atomic force microscopy. ACS Nano 2015, 9, 7960-7967. [CrossRef] [PubMed]

161. Yang, G.; Wong, M.K.; Lin, L.E.; Yip, C.M. Nucleation and growth of elastin-like peptide fibril multilayers: An in situ atomic force microscopy study. Nanotechnology 2011, 22, 494018. [CrossRef] [PubMed]

162. Charbonneau, C.; Kleijn, J.M.; Cohen Stuart, M.A. Subtle charge balance controls surface-nucleated self-assembly of designed biopolymers. ACS Nano 2014, 8, 2328-2335. [CrossRef] [PubMed]

163. Kang, S.-G.; Li, H.; Huynh, T.; Zhang, F.; Xia, Z.; Zhang, Y.; Zhou, R. Molecular mechanism of surface-assisted epitaxial self-assembly of amyloid-like peptides. ACS Nano 2012, 6, 9276-9282. [CrossRef] [PubMed]

164. Dai, B.; Kang, S.-G.; Huynh, T.; Lei, H.; Castelli, M.; Hu, J.; Zhang, Y.; Zhou, R. Salts drive controllable multilayered upright assembly of amyloid-like peptides at mica/water interface. Proc. Natl. Acad. Sci. USA 2013, 110, 8543-8548. [CrossRef] [PubMed]

165. Varongchayakul, N.; Johnson, S.; Quabili, T.; Cappello, J.; Ghandehari, H.; Solares, S.D.J.; Hwang, W.; Seog, J. Direct observation of amyloid nucleation under nanomechanical stretching. ACS Nano 2013, 7, 7734-7743. [CrossRef] [PubMed]

166. Yang, H.; Fung, S.-Y.; Pritzker, M.; Chen, P. Mechanical-force-induced nucleation and growth of peptide nanofibers at liquid/solid interfaces. Angew. Chem. Int. Ed. 2008, 47, 4397-4400. [CrossRef] [PubMed]

167. LeGeros, R.Z. Calcium phosphate-based osteoinductive materials. Chem. Rev. 2008, 108, 4742-4753. [CrossRef] [PubMed]

168. Tiselius, H.-G. A hypothesis of calcium stone formation: An interpretation of stone research during the past decades. Urol. Res. 2011, 39, 231-243. [CrossRef] [PubMed]

169. Bazin, D.; Daudon, M.; Combes, C.; Rey, C. Characterization and some physicochemical aspects of pathological microcalcifications. Chem. Rev. 2012, 112, 5092-5120. [CrossRef] [PubMed]

170. Li, M.; Wang, L.; Zhang, W.; Putnis, C.V.; Putnis, A. Direct observation of spiral growth, particle attachment, and morphology evolution of hydroxyapatite. Cryst. Growth Des. 2016, 16, 4509-4518. [CrossRef] 
171. Wu, S.; Yu, M.; Li, M.; Wang, L.; Putnis, C.V.; Putnis, A. In situ afm imaging of octacalcium phosphate crystallization and its modulation by amelogenin's c-terminus. Cryst. Growth Des. 2017, 17, 2194-2202. [CrossRef]

172. Habraken, W.J.; Tao, J.; Brylka, L.J.; Friedrich, H.; Bertinetti, L.; Schenk, A.S.; Verch, A.; Dmitrovic, V.; Bomans, P.H.; Frederik, P.M. Ion-association complexes unite classical and non-classical theories for the biomimetic nucleation of calcium phosphate. Nat. Commun. 2013, 4, 1507. [CrossRef] [PubMed]

173. Rodriguez-Navarro, C.; Burgos Cara, A.; Elert, K.; Putnis, C.V.; Ruiz-Agudo, E. Direct nanoscale imaging reveals the growth of calcite crystals via amorphous nanoparticles. Cryst. Growth Des. 2016, 16, 1850-1860. [CrossRef]

174. Wolf, S.L.P.; Caballero, L.; Melo, F.; Cölfen, H. Gel-like calcium carbonate precursors observed by in-situ afm. Langmuir 2016, 33, 158-163. [CrossRef] [PubMed]

175. Hofmann, S.; Voïtchovsky, K.; Spijker, P.; Schmidt, M.; Stumpf, T. Visualising the molecular alteration of the calcite (104)-water interface by sodium nitrate. Sci. Rep. 2016, 6, 21576. [CrossRef] [PubMed]

176. Wang, L.; Qin, L.; Putnis, C.V.; Ruiz-Agudo, E.; King, H.E.; Putnis, A. Visualizing organophosphate precipitation at the calcite-water interface by in situ atomic-force microscopy. Environ. Sci. Technol. 2015, 50, 259-268. [CrossRef] [PubMed]

177. So, C.R.; Liu, J.; Fears, K.P.; Leary, D.H.; Golden, J.P.; Wahl, K.J. Self-assembly of protein nanofibrils orchestrates calcite step movement through selective nonchiral interactions. ACS Nano 2015, 9, 5782-5791. [CrossRef] [PubMed]

178. Cho, K.R.; Salter, E.A.; De Yoreo, J.J.; Wierzbicki, A.; Elhadj, S.; Huang, Y.; Qiu, S.R. Growth inhibition of calcium oxalate monohydrate crystal by linear aspartic acid enantiomers investigated by in situ atomic force microscopy. CrystEngComm 2013, 15, 54-64. [CrossRef]

179. Li, S.; Zhang, W.; Wang, L. Direct nanoscale imaging of calcium oxalate crystallization on brushite reveals the mechanisms underlying stone formation. Cryst. Growth Des. 2015, 15, 3038-3045. [CrossRef]

180. Ando, T.; Uchihashi, T.; Fukuma, T. High-speed atomic force microscopy for nano-visualization of dynamic biomolecular processes. Prog. Surf. Sci. 2008, 83, 337-437. [CrossRef]

181. Li, Y.; Bechhoefer, J. Model-free iterative control of repetitive dynamics for high-speed scanning in atomic force microscopy. Rev. Sci. Instrum. 2009, 80, 013702. [CrossRef] [PubMed]

182. Yan, Y.; Wu, Y.; Zou, Q.; Su, C. An integrated approach to piezoactuator positioning in high-speed atomic force microscope imaging. Rev. Sci. Instrum. 2008, 79, 073704. [CrossRef] [PubMed]

183. Heinisch, J.J.; Lipke, P.N.; Beaussart, A.; Chatel, S.E.K.; Dupres, V.; Alsteens, D.; Dufrêne, Y.F. Atomic force microscopy-Looking at mechanosensors on the cell surface. J. Cell Sci. 2012, 125, 4189-4195. [CrossRef] [PubMed]

(C) 2017 by the authors. Licensee MDPI, Basel, Switzerland. This article is an open access article distributed under the terms and conditions of the Creative Commons Attribution (CC BY) license (http://creativecommons.org/licenses/by/4.0/). 